\begin{tabular}{|c|c|c|}
\hline \multirow{2}{*}{$\begin{array}{r}\text { Case Reports in } \\
\text { Gastroenterology }\end{array}$} & \multicolumn{2}{|c|}{ Case Rep Gastroenterol 2017;11:434-439 } \\
\hline & $\begin{array}{l}\text { DOI: 10.1159/000477716 } \\
\text { Published online: August 8, } 2017\end{array}$ & $\begin{array}{l}\text { (C) } 2017 \text { The Author(s) } \\
\text { Published by S. Karger AG, Basel } \\
\text { www.karger.com/crg }\end{array}$ \\
\hline & \multicolumn{2}{|c|}{$\begin{array}{l}\text { This article is licensed under the Creative Commons Attribution-NonCommercial } 4.0 \\
\text { International License (CC BY-NC) (http://www.karger.com/Services/OpenAccessLicense). } \\
\text { Usage and distribution for commercial purposes requires written permission. }\end{array}$} \\
\hline
\end{tabular}

\title{
Colonic Ganglioneuroma: A Rare Finding during Colorectal Cancer Screening
}

\author{
Emmanuel Ofori $^{a} \quad$ Mel Ona $^{a}$ Daryl Ramai ${ }^{a, c}$ Tiangui Huang ${ }^{b}$ \\ Philip Xiao ${ }^{b}$ Madhavi Reddy ${ }^{a}$ \\ ${ }^{a}$ Department of Gastroenterology and Hepatology, The Brooklyn Hospital Center, \\ Academic Affiliate of The Icahn School of Medicine at Mount Sinai, Clinical Affiliate of \\ The Mount Sinai Hospital, Brooklyn, NY, USA; ${ }^{b}$ Department of Pathology, The Brooklyn \\ Hospital Center, Academic Affiliate of The Icahn School of Medicine at Mount Sinai, \\ Clinical Affiliate of The Mount Sinai Hospital, Brooklyn, NY, USA; 'Department of \\ Anatomical Sciences, St. George's University School of Medicine, True Blue, Grenada
}

\section{Keywords}

Ganglioneuroma - Autonomic nervous system - Ascending colon · Screening colonoscopy · S100 tumor

\begin{abstract}
Ganglioneuromas are very rare clinical entities, and their occurrence in the large bowel lays further emphasis on their rarity. Ganglioneuromas are benign tumors of undifferentiated neural crest cells. Their clinical presentation is mostly asymptomatic, and if any symptoms are present at all, they are usually nonspecific, with excellent prognosis. We report an asymptomatic, 65-year-old male with a solitary ascending colonic polyp found on screening colonoscopy. Histology revealed benign polypoid spindle-cell proliferation as well as S100 reactivity, consistent with ganglioneuroma. We report on the clinical presentation and discuss the origin, epidemiology, treatment, and management of this lesion.
\end{abstract}

(c) 2017 The Author(s)

Published by S. Karger AG, Basel 


\section{Introduction}

Ganglioneuromas are rare and benign tumors of the sympathetic nervous system composed of ganglion cells, nerve fibers, and glial cells, which originate from neural crest cells [1]. Solitary ganglioneuromas should be distinguished from ganglioneuromatous polyposis and diffuse ganglioneuromatosis. They are not associated with genetic syndromes such as neurofibromatosis 1 , multiple endocrine neoplasia 2B syndrome, and juvenile polyposis. Clinically, patients are either asymptomatic or present with vague symptoms of abdominal pain, constipation, weight loss, bleeding, and signs of bowel obstruction [2]. Though there are no current guidelines, most clinicians agree that surveillance colonoscopy is not necessary following endoscopic resection. Herein, we describe a case of a 65-year-old male with an ascending colonic polyp found on screening colonoscopy, which proved to be a ganglioneuroma following histopathology.

\section{Case Presentation}

A 65-year-old male with a medical history of chronic obstructive pulmonary disease with partial right-lung resection 16 years ago, hypertension, diabetes mellitus type 2, and gastroesophageal reflux disease presented for colonoscopy for colorectal cancer screening. Our patient, who is a nonsmoker, did not report any active complaints or symptoms. Physical examination was unremarkable. The heart rate was $101 / \mathrm{min}$, and he had a blood pressure of $158 / 83 \mathrm{~mm} \mathrm{Hg}$, a respiratory rate of $20 / \mathrm{min}$, an oxygen saturation of $95 \%$ on room air, and a temperature of $98.4^{\circ} \mathrm{F}$. Laboratory findings showed a white cell count of $10 \times 10^{9} / \mathrm{L}$, hemoglobin of $13.5 \mathrm{~g} / \mathrm{dL}$, hematocrit of $41 \%$, and platelets of $359 \times 10^{9} / \mathrm{L}$.

During screening colonoscopy, 2 nonbleeding polyps were identified in the ascending colon, measuring $6 \mathrm{~mm}$ each. Both polyps were removed by cold forceps excisional polypectomy. Following histopathology, hematoxylin and eosin staining showed spindle-cell proliferation, and immunohistochemistry demonstrated S100 immunoreactivity, consistent with ganglioneuroma (Fig. 1, Fig. 2, Fig. 3).

\section{Discussion}

Ganglioneuromas are benign hamartomatous tumors of the autonomic nervous system [1]. As a subtype of tumors of undifferentiated neuroblastic origin, ganglioneuromas are composed of ganglion cells, nerve fibers, and supportive glial cells [3, 4]. Ganglioneuromas are uncommon worldwide and can occur at any autonomic location. However, a review of published cases shows that ganglioneuromas have a predilection for the head, neck, and or adrenal glands [2]. Furthermore, ganglioneuromas bear no predilection for gender and have been detected among adults in their 3rd-10th decades of life with peak incidence between the 4 th and 6 th decades $[5,6]$.

Gastrointestinal ganglioneuromas are morphologically classified into 3 categories, namely polypoid ganglioneuromas, ganglioneuromatous polyposis, and diffuse ganglioneuromatosis [7]. Polypoid ganglioneuromas are mostly solitary, small (measuring $<2 \mathrm{~cm}$ ), and may be sessile or pedunculated polyps [6]. Ganglioneuromatous polyposis are multiple, mostly more than 20 , ranging from $1 \mathrm{~mm}$ to $2.2 \mathrm{~cm}$ in size, and can also be sessile or pedunculated. Some may be filiform [6]. Ganglioneuromas classically occupy the lamina propria 
but can extend into the submucosa. Diffuse ganglioneuromatosis is nodular and diffuse, up to $17 \mathrm{~cm}$ in size, and often extends transmurally to involve the myenteric plexus [8].

Ganglioneuromatous polyposis and diffuse ganglioneuromatosis are associated with genetic syndromes such as neurofibromatosis 1 , multiple endocrine neoplasia 2B syndrome, and juvenile polyposis. However, solitary ganglioneuromas are not associated with systemic and familial syndromes [9]. Patients with solitary ganglioneuromas are usually asymptomatic and are detected on routine colorectal cancer screening. However, some patients may present with vague symptoms of abdominal pain, constipation, weight loss, hematochezia, and signs of obstruction [2]. While hematochezia due to a solitary ganglioneuroma is very rare, a review of the literature shows that bleeding is highly associated with this tumor [2, $10,11]$. However, the majority of patients is asymptomatic or presents with chronic diarrhea [12].

Endoscopically, intestinal ganglioneuromas have no discerning phenotypic characteristics. They are definitively diagnosed by biopsy followed by histology, which demonstrates immunoreactivity to S100 with comma-shaped nuclei mixed with aggregates of ganglion cells. Ganglioneuromas can also be positive for vimentin, glial fibrillary acidic protein, and neuron-specific enolase. Hematoxylin and eosin staining usually shows a high proliferative index of spindle cells with a collection of ganglion cells [6].

Gastrointestinal ganglioneuromas are usually treated endoscopically and completely excised. Currently, no guideline exists on the management of solitary ganglioneuromas or recommendations for surveillance colonoscopy. However, most authors agree that repeat colonoscopy is not necessary due to the benign nature of the lesion, which tends not to recur $[6,13,14]$. Furthermore, prognosis is usually excellent and without complications. Evidently, a study of 28 patients with solitary ganglioneuromas found that after an average follow-up time of 8 years, none of the patients developed von Recklinghausen disease, multiple tumor syndromes, or subsequent complications [7].

In conclusion, gastrointestinal ganglioneuromas are rare and benign hamartomatous tumors that originate from the autonomic nervous system. Bearing no predilection for gender, the average incidental age is 50 years with excellent patient prognosis. Solitary ganglioneuromas are not associated with any systemic or genetic conditions and tend not to recur. As a result, they can be safely excised endoscopically without complications. Our patient was similarly treated with a favorable clinical outcome.

\section{Statement of Ethics}

Informed consent was obtained from the patient.

\section{Disclosure Statement}

The authors have no conflicts of interest or financial relationships to disclose. 
Ofori et al.: Colonic Ganglioneuroma: A Rare Finding during Colorectal Cancer Screening

\section{Author Contribution}

E.O., M.O., D.R., and M.R. were responsible for the conception, design, and the drafting of the article. E.O., M.O., D.R., M.R., T.H., and P.X. critically revised the article for important intellectual content. E.O., M.O., D.R., M.R., T.H., and P.X. gave final approval to the article.

\section{References}

1 Chan OTM, Haghighi P: Hamartomatous polyps of the colon: ganglioneuromas, stromal, and lipomatomous. Arch Pathol Lab Med 2006;130:1561-1566.

2 Abraham G, Prakash SR: Solitary colonic ganglioneuroma: a rare incidental finding of hematochezia. Case Rep Gastrointest Med 2015;2015:794985.

-3 Shimada H, Chatten J, Newton WA Jr, Sachs N, Hamoudi AB, Chiba T, Marsden HB, Misugi K: Histopathologic prognostic factors in neuroblastic tumors: definition of subtypes of ganglioneuroblastoma and an age-linked classification of neuroblastomas. J Natl Cancer Inst 1984;73:405-416.

-4 Shimada H, Ambros IM, Dehner LP, Hata J, Joshi VV, Roald B, Stram DO, Gerbing RB, Lukens JN, Matthay KK, Castleberry RP: The International Neuroblastoma Pathology Classification (the Shimada system). Cancer 1999;86:364-372.

5 Bakker JR, Haber MM, Garcia FU: Gastrointestinal neurofibromatosis: an unusual cause of gastric outlet obstruction. Am Surg 2005;71:100-105.

-6 Voltaggio L, Montgomery EA: Gastrointestinal tract spindle cell lesions - just like real estate, it's all about location. Mod Pathol 2015;28:S47-S66.

7 Shekitka KM, Sobin LH: Ganglioneuromas of the gastrointestinal tract: relation to von Recklinghausen disease and other multiple tumor syndromes. Am J Surg Pathol 1994;18:250-257.

$>8$ Chambonniere ML, Porcheron J, Scoazec JY, Audigier JC, Mosnier JF: Intestinal ganglioneuromatosis diagnosed in adult patients. Gastroenterol Clin Biol 2003;27:219-224.

-9 Ledwidge SF, Moorghen M, Longman RJ, Thomas MG: Adult transmural intestinal ganglioneuromatosis is not always associated with multiple endocrine neoplasia or neurofibromatosis: a case report. J Clin Pathol 2007;60:222-223.

10 Dellinger GW, Lynch CA, Mihas AA: Colonic ganglioneuroma presenting as filiform polyposis. J Clin Gastroenterol 1996;22:66-70.

11 Rafiq S, Hameer H, Sitrin MD: Ganglioneuromatous polyposis associated with juvenile polyps and a tubular adenoma. Dig Dis Sci 2005;50:506-508.

$\checkmark 12$ Sayki Arslan M, Ekiz F, Yilmaz G, Coban S, Savas B, Ensari A, Ormeci N: Ganglioneuromatous polyposis of the colon in a patient with multiple adenomatous polyps. Turk J Gastroenterol 2012;23:780-783.

13 Srinivasan R, Mayle JE: Polypoid ganglioneuroma of colon. Dig Dis Sci 1998;43:908-909.

14 Herman M, Abed J, Shi W, Buyuk A, Mankal PK, Kotler D, Ionescu G: A case of ganglioneuroma of the colon during routine colonoscopy. Int J Case Rep Imag 2015;6:560-563. 


\section{Case Reports in \\ Gastroenterology
Case Rep Gastroenterol 2017;11:434-439
DOI: $10.1159 / 000477716$
(c) 2017 The Author(s). Published by S. Karger AG, Basel www.karger.com/crg \\ Ofori et al.: Colonic Ganglioneuroma: A Rare Finding during Colorectal Cancer Screening}

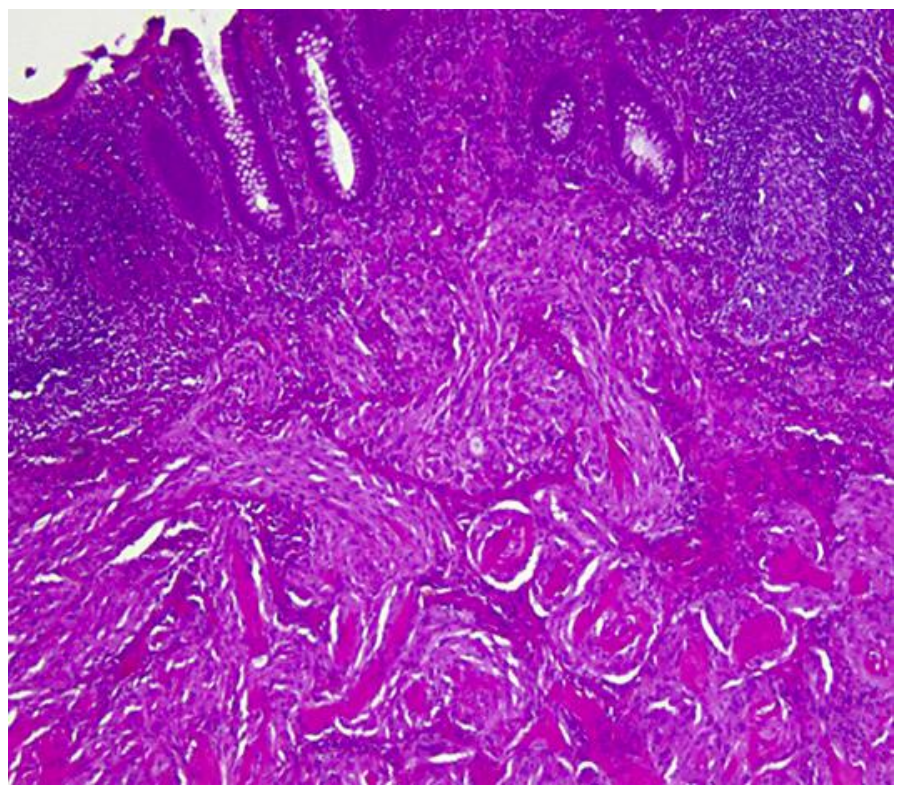

Fig. 1. Hematoxylin and eosin staining showing ganglion and stromal cells. Magnification, $\times 40$.

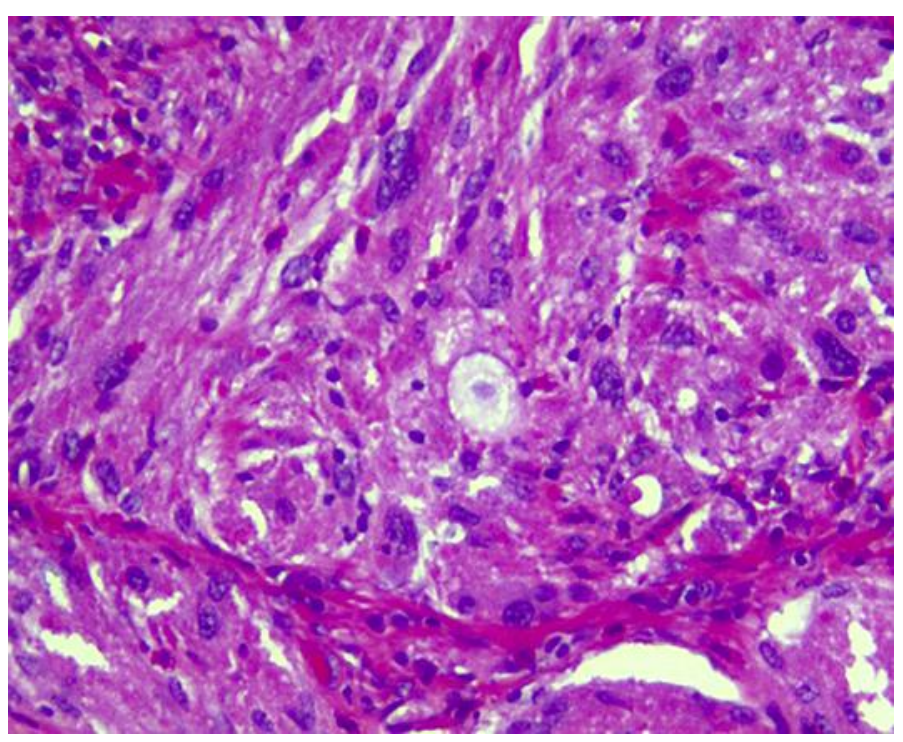

Fig. 2. Hematoxylin and eosin staining revealing nodular expansion of neural bundle and ganglion cells. Magnification, $\times 100$. 


\begin{tabular}{|c|c|c|}
\hline \multirow{3}{*}{$\begin{array}{r}\text { Case Reports in } \\
\text { Gastroenterology }\end{array}$} & \multirow{2}{*}{\multicolumn{2}{|c|}{ Case Rep Gastroenterol 2017;11:434-439 }} \\
\hline & & \\
\hline & DOI: $10.1159 / 000477716$ & $\begin{array}{l}\text { ( ) } 2017 \text { The Author(s). Published by S. Karger AG, Basel } \\
\text { www.karger.com/crg }\end{array}$ \\
\hline
\end{tabular}

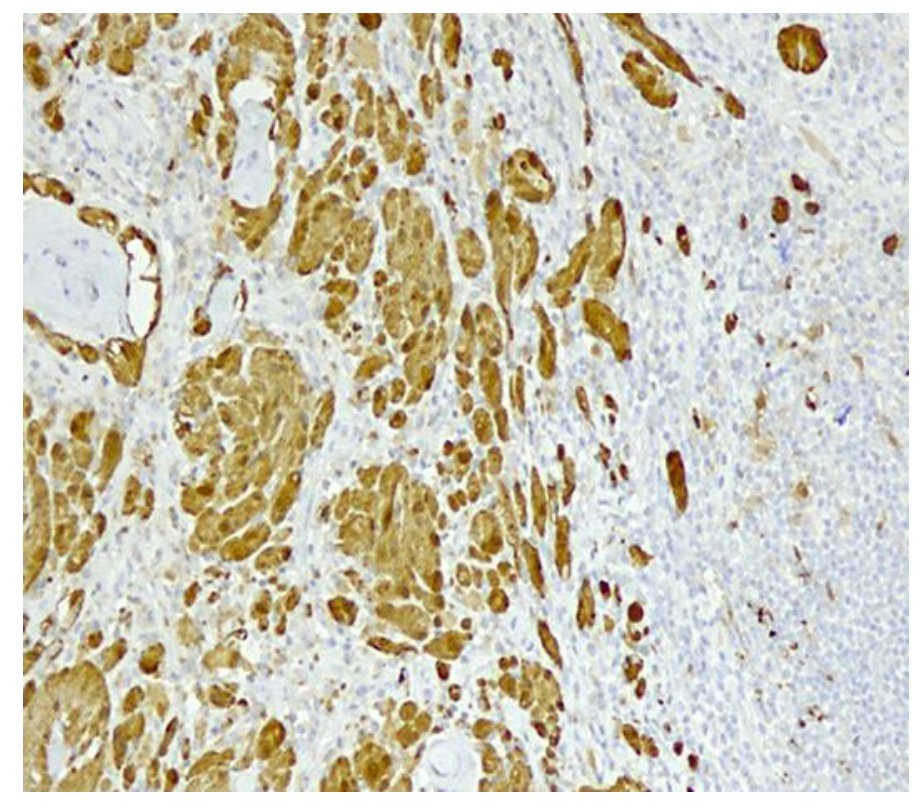

Fig. 3. Immunohistochemical staining demonstrating S100 immunoreactivity. Magnification, $\times 40$. 